\title{
TEPMIHOЗНАВСТВО
}

УДК 81’373.612.2:37.0

В. А. Борисов

\section{МЕТАФОРА В ОСВІТНЬОМУ ДИСКУРСІ}

У розвідиі розкрито роль метабори в освітньому дискурсі. 3'ясовано, що ії застосування сприяє виробленню своєрідного стилю бачення дискурсивної картини світу, активізації розумової і пізнавальної діяльності учасників освітнього процесу. Установлюючи зв'язок між різноманітними завданнями для здобувачів освіти, поєднуючи зазначене в метаборичних образах, викладач у такий спосіб полегшує аудиторії сприйняття інформації, дає змогу будувати образи у свідомості. Метабора в мовленні освітян робить зміст тексту иікавим і зрозумілим, впливає на інтелект, почуття та волю реципієнта, посилює сприймання ним інформації.

Ключові слова: освітній дискурс, концептуальна метафора, метафоризація, концепт, прагматика, дескриптивний метод, термінознавство, наукова комунікація.

Borysov V. Metaphor in Educational Discourse. The article deals with the role of a metaphor in educational discourse. It has been found out that the use of metaphors in educational discourse contributes to the development of the unique style of vision of the discursive worldview, activation of mental and cognitive activity of the educational process participants. By connecting various tasks for students, combining metaphorical images, a teacher facilitates the audience's perception of information, helps students to create images. Metaphors in educators' speech make the content of the text interesting and clear, affect recipients' intellect, feelings and will, enhance their perception of information. This is possible on the condition of understanding human thinking, studying mental processes. A metaphor is an important component of teachers' self-realization and professional development, as the correct selection of conceptual metaphors requires perfect knowledge of the material, as well as establishing contact with the educational process recipients.

Conceptual metaphors project into a person's conceptual system such a perspective through which he or she sees the world around, gets new ways to study phenomena, according to the developed theory of a conceptual metaphor the interaction of knowledge structures (frames and scenarios) of two conceptual domains takes place in the process of metaphorization. A conceptual metaphor as a structural element of a text fulfills its function, which ensures coherence and integrity of a text, and enhances its aesthetic significance and pragmatic potential. 
A conceptual metaphor in the texts of educational discourse is the possibility of language implementation, from the traditional lexical and semantic variation to the model involved in the construction of a holistic text or discourse, as well as a means of language implementation of speech influence. Specific concepts that are inherent in consciousness, in the process of metaphorization are transformed into models for understanding complex concepts related to different spheres of a human life. A conceptual metaphor is used unconsciously and automatically and is formed not by logical but by complex thinking. A metaphor gives a fuller understanding and clarification of the educational process essence, as well as the emergence of new logical and complex inferences.

Key words: educational discourse, conceptual metaphor, metaphorization, concept, pragmatics, descriptive method, terminology, scientific communication.

\section{Вступ}

Активне вивчення дискурсу розпочалося в другій половині XX століття, при цьому він одразу став предметом міждисциплінарних досліджень, що зумовило виникнення різних підходів до визначення його особливостей. Освітній дискурс $є$ різновидом інституційного дискурсу, що більшою мірою віддзеркалює запити суспільства, адже його мета полягає у формуванні комунікативних здатностей особистості з позицій науковості, доступності, соціальних чинників функціонування, $є$ відкритою динамічною системою за структурою і змістом.

Зміни в змісті й структурі освітнього дискурсу як лінгвістичної категорії відбуваються у вживанні нових понять, часто запозичених з інших дискурсів або з освітнього дискурсу тих чи тих культур. Однак варто зауважити, що передусім відбувається запозичення соціокультурних феноменів, яке згодом зумовлює зміну дискурсу.

Освітній дискурс, як уважає Г. Каннелла, виник у добу Просвітництва у зв'язку з формуванням наукового підходу до осмислення проблем освіти. Саме тоді науковці вперше замислилися над тим, які є потреби в знаннях різних вікових категорій населення, що саме вони здатні засвоїти в певному віці, як їм донести знання, які методи й технології при цьому використовувати (Канелла, 1999). Освітній дискурс як об'єкт сучасних досліджень вивчають крізь призму сучасних наук, методологій і методів: у наукових працях представлено безліч підходів, демонструється використання традиційних і новітніх дослідницьких методик та алгоритмів. Зважаючи на це, предметні зв’язки 
в межах аналізованого об’єкта виявляються недостатніми та вимагають уточнень, що торкаються його суті, меж і змісту.

В освітньому дискурсі значна роль відведена тропам, зокрема метафорі. У лінгвістичних студіях (Н. Д. Арутюнова, М. Джонсон, Дж. Лакофф, О. О. Селіванова, В. М. Телія та ін.) метафору традиційно досліджують як суто мовленнєвий засіб, що набуває нової лінгвокогнітивної спрямованості в дискурсі. Це пов'язано з появою і розвитком теорії концептуальної метафори як операції мислення; положення цієї теорії використовують у багатьох сучасних розвідках щодо концептуальних метафор освітнього дискурсу як інструментів когнітивного моделювання лексикону фахової сфери.

Мета цієї статті - з'ясувати особливості та функціонування метафори в освітньому дискурсі. Зазначена мета передбачає розв'язання таких завдань: 1) сформувати й уточнити поняття освітнього дискурсу; 2) проаналізувати види метафор; 3) висвітлити особливості функціонування концептуальної метафори в освітньому дискурсі.

\section{Методи дослідження}

Для досягнення мети й реалізації поставлених завдань використовуємо загальнонаукові методи аналізу й синтезу (для здійснення теоретичних узагальнень і систематизації фактичного матеріалу), метод етимологічного аналізу (для простеження генези фактичного матеріалу), дескриптивний метод (для вивчення однорідних елементів мови), метод спостереження (для процесу передбачення наявності задуму, мети та засобів спостереження до результатів спостереження) та дискурсивний метод (для опису текстових структур).

\section{Виклад основного матеріалу}

Загальновідомо, що метафора - це стилістичний прийом, заснований на реалізації двох лексичних значень на основі перенесення за подібністю. Метафора $є$ найбільш ефективним засобом створення образності. Вона працює не тільки там, де немає інших засобів для адекватного вираження нового змісту, а й там, де усвідомлюється необхідність у вираженні прагматичного аспекту комунікації, оскільки сприйняття метафори змушує реципієнта розгадати їі задум і в такий спосіб - «підключити до індикативного режиму декодування механізми розпізнання прагматичного ії коду, непорушним компонентом 
якого є установка автора промови на певний ілокутивний ефект» (Телія, 1986: 83).

Існує низка класифікацій метафор за різними вченнями: І. Р. Гальперін розподіляє метафори за ступенем їхньої непередбачуваності: справжні метафори й метафори, що втратили образність, або мовні (Гальперин, 1981).

Н. Д. Арутюнова виокремлює за функціональними ознаками такі типи метафор:

1) номінативна, або власне перенесення назви, що проявляється внаслідок заміни одного дескриптивного значення іншим і слугує джерелом омонімії;

2) образна метафора, яка з'являється внаслідок переходу дескриптивного значення в предикатне й сприяє розвитку синонімічних засобів мови;

3) когнітивна метафора, що виникає внаслідок сполучуваності ознакових слів (перенесення значення) і створює полісемію;

4) генералізується, тобто стирає в лексичному значенні межі (Арутюнова, 1978).

А. П. Гаврилюк зауважує, що «метафора як мовна і мовленнєва одиниця виконує декілька різних функцій, залежно від яких вона може розглядатись як стилістичний прийом, як спосіб образного вираження змісту, як спосіб пізнання та номінації нових понять та як спосіб мислення» (Гаврилюк, 2013: 32).

Якщо звернутися до етимології терміна метафора, то він по-

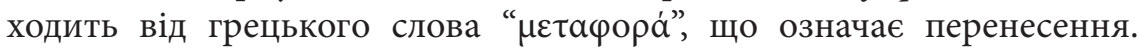
Перше визначення фіксуємо в «Поетиці» Аристотеля, відповідно до якого «метафора - це перенесення слова зі зміненим значенням з роду на вид, або з виду на вид, або за аналогією» (Аристотель, 1998: 1097). Із зазначеного зрозуміло, що метафора виникає на основі перенесення властивостей, тобто метафора - це перенесення за аналогією, за схожістю або подібністю, за асоціацією. Поняття асоціації пов'язане з мисленнєвою діяльністю мовця, тому воно є причиною або поштовхом до виникнення метафори.

Вивчення метафори в науковому стилі містить низку суперечностей, а саме: а) проблема кваліфікації метафори як джерела термінотворчості; б) наявність у наукових текстах метафор, що не втратили образності. На нашу думку, втрата образності $€$ незворотною, якщо 
йдеться про спеціальну одиницю поза контекстом; у текстах досліджуваної тематики будь-яка одиниця із втраченою образністю може пожвавлюватися через залучення до мікроконтексту слів, що належать одному асоціативному полю. Традиційно термінологічна омонімія, полісемія й синонімія є явищами, не зовсім властивими або вкрай небажаними для термінології. Небажаною вважають наявність у терміна експресивної конотації та образності, що робить метафору джерелом “засмічення” системи спеціальних позначень, перешкоджаючи кодифікації.

Сьогодні акцент зміщується в бік дескриптивного методу дослідження термінознавства: термін, як і будь-яка знакова одиниця, вивчають у царині функціонування (в тексті) в синтаксичному, семантичному й прагматичному аспектах. У прагматиці особливий інтерес науковців викликає вплив когнітивної структури терміна-неологізма або неоніма на дискурс. Зазначимо, що, окрім елемента новизни, така некодифікована термінологічна одиниця сприяє непомітному введенню в текст певного погляду на будь-яку ситуацію й створює аксіологічну стратегію; допомагає читачеві правильно та чітко поцінувати описану подію, пропонуючи готове судження й цим забезпечує імпліцитний вплив на думку адресата. У зв'язку із цим особливий інтерес викликає роль метафори в текстах професійного спрямування. У прагматичному аспекті значущості набувають аналогії, у яких подібність та відмінність системно сформульовані й чітко визначені, так само метафоричні позначення мають переваги. О. О. Селіванова виділяє п’ять напрямів вивчення метафори. Згідно з логіко-філософським «метафора $є$ результатом формування спільної думки про предмет, явище на підставі виділення спільної ознаки» (Селіванова, 2011: 388-389).

Серед численних варіантів дескриптивного аналізу освітнього дискурсу є і присвячені вивченню метафори. Це, зокрема, теорія дискурсивного розуміння (Й. Вальтер, Й. Хельміг, Р. Хюльссе), у якій метафора проаналізована не як спосіб аргументації, а як соціальний феномен, як відображення загальних для певної групи людей уявлень, що суттєво впливають на конструювання соціальної реальності. Відповідно до цієї теорії, сам дискурс породжує метафори, які стають його помічниками. При цьому індивідуально-когнітивним особливостям освітньої комунікації відводиться незначна роль. 
Оскільки об’єктом нашого дослідження є освітній дискурс, цілком природно, що реципієнт текстів професійного спрямування залучений до сфери наукової комунікації. Це конкретний споживач, вікові й інтелектуальні властивості якого необхідно враховувати. Тож можна прогнозувати особливу прагматичну роль термінів освіти, утворених шляхом метафоричного перенесення, у текстах професійного спрямування. На винятково важливій ролі метафори в освітньому дискурсі наголошував Б. Б. Комаровський ще в 1969 році. Однак метафору розуміли як замінник терміна: «Там, де педагогіка не може висловити свої ідеї в науково обгрунтованих термінах, вона вдається до метафори» (Комаровський, 1969). Із цим твердженням погодитися важко, оскільки “замінником терміна” традиційно вважається дефініція, якою не є метафора. Імовірно, що це твердження було викликане небажанням визнавати продуктивність семантичного способу термінотворення. Компактне експліцитно-формальне подання інформації в досліджуваних текстах можливе лише за умови використання стилістичних засобів, зокрема метафори, оскільки вона дає змогу виявити на текстовому рівні способи моделювання всіх складників освітнього дискурсу.

Зокрема, освітній простір - уже не метафора, але ще не термін. В. М. Полонський слушно зауважує, що ця одиниця не має поняттєвої ваги, а контекстна ії реалізація забезпечується завдяки метафорі. Усі спроби виділити категорії і властивості в межах поняття ведуть до асоціативних перенесень, результатом яких є образні найменування, що позбавлені чіткого поняттєвого змісту. Метафора в освітньому дискурсі може виконувати пояснювальну функцію щодо абстрактних понять та явищ, які складно пояснити словами в прямому значенні, сприяти створенню нових термінів, оскільки в метафоризації з усього набору лексико-семантичних варіантів слова реалізується лише один. Метафора в широкому розумінні функціонує в мові й мисленні будь-якого простору. Як уже зауважувалось, завдяки метафоричним процесам відбувається пізнання та номінація, семантика розвивається як у семасіологічному, так і в ономасіологічному аспектах, виникають нові терміни, мовні вислови, словосполучення, а отже, метафори стають словами та висловами загального вжитку.

I. В. Вачков виокремлює основні метафоричні механізми: 1) екстраполяція прихованих смислів, сутність якої полягає в тому, 
що в суб’єкта виникає змога черпати з метафори той зміст, що відповідає його світорозумінню й баченню своїх проблем; 2) пробудження творчих ресурсів уяви; 3) семантичне опосередкування (метафори стають сполучною ланкою між семантичними просторами педагога й адресата; 4) актуалізація архетипів (метафори залучають глибинні механізми несвідомого завдяки незвичних для розуму архетипних елементів); 5) фасилітація (метафори полегшують усвідомлення системи відносин між суб'єктами й знижують вплив негативних емоцій при одержанні хворобливої для суб'єкта інформації; автор уважає, що метафори діють набагато м’якше й делікатніше, ніж багато інших засобів впливу) (Вачков, 2006: 123-124).

Нині вивчення дискурсивної освітньої метафори набуває лінгвокогнітивної орієнтації, тобто наразі аналіз концептуальної метафори становить одне з провідних завдань сучасної лінгвістики. Теорія концептуальної метафори активно розвивається, набуває нових наукових інтерпретацій і переходить у нові галузі застосування. Розуміння ролі метафори в процесі номінації полягає в тому, що вона є тим когнітивним механізмом, за допомогою якого абстрактні поняття осмислюються в більш конкретних термінах, тому метафора - це один iз фундаментальних прийомів пізнання і концептуалізації реалій сьогодення. Концептуальна метафора може слугувати ефективним знаряддям впливу на свідомість людини, оскільки зрозуміло, що джерелами метафоричної експансії є особливо актуальні для суспільства реалії. За основу візьмемо типологію концептуальної метафори, зокрема принцип номінації моделей, запропонований Н. О. Мишанкіною, а саме: метафори виокремлюються за допомогою предикативної структури, що віддзеркалює вихідну й результативну поняттєві сфери «суперечка - це війна». Онтологічні метафори маркуються лаконічно: «об’єкт - умістилище». Однак у процесі утворення онтологічної метафори взаємодіють дві поняттєві сфери: загальні уявлення про властивості об'єкта й будь-яка інша, найчастіше абстрактного характеру, тому було б доцільніше використовувати номінацію «абстрактна сутність - це об’єкт» або «щось - це об’єкт» (Мишанкіна, 2010: 126).

Зазначимо, що найбільш активними джерелами метафор є такі поняттєві царини, як “освіта”, “заклади освіти”, “здобувачі освіти”, “галузі освіти”, “нормативні документи” та інші. Осмислення науки взагалі й окремих галузей, зокрема освіти, реалізується передусім 
на основі просторової метафори, тобто «освіта - це простір»: на межі галузей знань; на межі наук; у межах пілотного проєкту; коло наукових інтересів; коло навчальних дисциплін; коло знань; коло проиесів і явищ, в освітніх програмах.

Досягнення “глибоко прихованого” об’єкта - мета освітньої дії і їі результат: глибокі знання дисциплін; глибокий аналіз проблеми; глибоке розуміння питання; глибока відповідь.

Кожен простір може бути вмістилищем відповідно до інших абстрактних сутностей, що є складниками його змісту - речовинне й об'єктне: навчальні дисиипліни у закладах вищої освіти містять вибіркові; робоча програма дисиипліни містить політику доброчесності.

У моделі «простір - умістилище» можуть бути репрезентовані будь-які абстракції: ие не входить у коло нашого дослідження; ми не ставили за мету залучати таку кількість тем до студентської наукової конферениіі.

Як просторова позиція, що необхідна для адекватного правильного сприйняття об'єкта, є інша абстрактна сутність: ие бачимо з того, як збільшився відсоток якісной успішності здобувачів освіти; ие видно з ліцензування закладів освіти.

Продуктивними є метафори, семантика яких апелює до складності й значущості певного об’єкта, а також має оцінне маркування: лекиія була проведена на високому науковому й методичному рівнях; здобувачі освіти на третьому курсі досягли більш високого професійного рівня розвитку; рівень знань; рівень розвитку інформаційних технологій; рівень акредитації.

Сукупність абстрактних сутностей, що моделюються на основі онтологічної метафори, це «щось - об'єкт», надзвичайно широкий у текстах професійного спрямування: форми контролю знань здобувачів освіти. У цьому разі абстрактна сутність представлена як об’єкт, який має здатність зберігати постійну форму.

Онтологічна метафора «щось - речовина» дає змогу акцентувати увагу на властивостях, що протиставляють останню об’єкту, на відсутність чіткої інформації про нього. Репрезентація абстрактної сутності, яка має речовинне походження, дає змогу оперувати нею. Найчастіше вихідною поняттєвою сферою є уявлення про рідку речовину. Імовірно, що основою цього вибору слугують цілком певні 
властивості речовини / рідини, це дає змогу змоделювати такі характеристики зазначених об’єктів, як наявність деякої загальної домінантної властивості: про ие дізнаємося з різних джерел; джерелом походження $\epsilon$; джерело дослідження; джерело знань. Тож онтологічна метафора «щось - речовина» забезпечує сприйняття абстрактної сутності завдяки актуалізації значущих для автора параметрів.

\section{Висновки}

Уміння адекватно використовувати ті чи ті лексико-семантичні засоби у формуванні тезаурусу освітнього дискурсу, зокрема метафоричні моделі, допомагає вирішувати наукові, методичні, виховні завдання в галузі освіти. Концептуальна метафора має здатність вербальної реалізації: від традиційного лексико-семантичного варіювання до моделі, що бере участь у вибудовуванні цілісного тексту або дискурсу. Як базова когнітивна модель, заснована на аналогіі та яка дає змогу осмислювати об’єкти і явища на основі знань про інші об’єкти і явища. Вона має продуктивність у мові, тексті, дискурсі у вигляді цілісної системи метафоричних висловів.

На нашу думку, необхідні подальші дослідження для того, щоб розкрити потенціал залучення концептуальної метафори до освітнього дискурсу. Для реалізації мети доцільно використати метод метафоричного моделювання й аналізу текстів професійного спрямування.

\section{ЛІТЕРАТУРА}

1. Аристотель. (1998). Об искусстве поэзии. Этика. Политика. Риторика. Поэтика. Категории. Минск: Литература. 2. Арутюнова, Н. Д. (1978). Функциональные типы языковой метафоры. Изв. АН СССР. Серия лит-ры и языка, 37 (4), 333-343. 3. Вачков, И. В. (2006). Метафорический тренинг. Москва: Ось-89. 4. Гаврилюк, А. П. (2013). Метафора, її природа та роль у мові та мовленні. Вісн. Наи. техн. ун-ту України «Київ. політехн. ін-т». Серія «Філологія. Педагогіка», 2, 29-33. 5. Гальперин, И. Р. (1981). Текст как объект лингвистического исследования. Москва: Наука. 6. Комаровский, Б. Б. (1969). Русская педагогическая терминология. Москва: Просвещение. 7. Мишанкина, Н. А. (2010). Метафора в науке: парадокс или норма? Томск: Изд-во Том. ун-та (с. 126). 8. Полонский, В. М. (1999). Понятийно-терминологический аппарат педагогики. Вестн. Рос. гуманит. науч. бонда, 3, 213-222. 9. Селіванова, О. О. (2011). Лінгвістична енциклопедія. Полтава: Довкілля-К. 10. Телия, В. Н. (1986). Коннотативный аспект семантики номинативных единии. Москва: Наука. 11. Cannella, G. S. (1999). The Scientific Discourse of Education: predetermining the lives of others - Foucault, education, and children. Contemporary Issues in Early Childhood, 1 (1), $36-44$. 


\section{REFERENCES}

1. Aristotel (1998). Ob iskusstve poezii. Etika. Politika. Ritorika. Poetika. Kategorii [About the Art of Poetry. Ethics. Politics. Rhetoric. Poetics. Categories] Minsk: Literatura [in Russian]. 2. Arutyunova, N. D. (1978). Funktsionalnye tipy yazykovoy metafory [Functional Types of Language Metaphor] Izv. AN SSSR, ser. lit-ry i yazyka - Izvestia of the USSR Academy of Sciences. Series of literature and language, 37 (4), 333-343. 3. Vachkov, I. V. (2006). Metaforicheskiy trening [Metaphorical Training]. Moskva: Os-89 [in Russian]. 4. Havryliuk, A. P. (2013). Metafora, yii pryroda ta rol u movi ta movlenni [Metaphor, its Nature and Role in Language and Speech]. Visn. Nats. tekhn. un-tu Ukrainy "Kyiv. politekhn. in-t». Seriia «Filolohiia. Pedahohika» - Bulletin of the National Technical University of Ukraine «Kiev Polytechnic Institute». Series «Philology. Pedagogy», 2, 29-33 [in Ukrainian]. 5. Galperin, I. R. (1981). Tekst kak obekt lingvisticheskogo issledovaniya [Text as an Object of Linguistic Research]. Moskva: Nauka [in Russian]. 6. Komarovskiy, B. B. (1969). Russkaya pedagogicheskaya terminologiya [Russian Pedagogical Terminology]. Moskva: Prosveshchenie [in Russian]. 7. Myshankyna, N. A. (2010). Metafora v nauke: paradoks ili norma? [Metaphor in Science: Paradox or Norm?]. Tomsk: Yzd-vo Tom. un-ta [in Russian] 8. Polonskiy, V. M. (1999). Ponyatijno-terminologicheskij apparat pedagogiki [Conceptual and terminological apparatus of pedagogy]. Vestn. Ros. gumanit. nauch. fonda - Bulletin of the Russian Foundation for the Humanities, 3, 213-222 [in Russian]. 9. Selivanova, O. O. (2011). Linhvistychna entsyklopediia [Linguistic Encyclopedia]. Poltava: Dovkillia-K [in Ukrainian]. 10. Teliya, V. N. (1986). Konnotativnyy aspekt semantiki nominativnykh edinits. [Connotative Aspect of Nominative Units Semantics]. Moskva: Nauka [in Russian]. 11. Cannella, G S. (1999). The Scientific Discourse of Education: predetermining the lives of others - Foucault, education, and children. Contemporary Issues in Early Childhood, 1 (1), 36-44 [in English].

Борисов Володимир Андрійович - кандидат філологічних наук, доцент, проректор з навчально-наукової роботи, Харківський національний педагогічний університет імені Г. С. Сковороди; вул. Алчевських, 29, м. Харків, 61002, Україна.

Тел.: +38050-620-66-45

E-mail: borisovl@icloud.com

http://orcid.org/0000-0000-6185-5649

Borysov Volodymyr Andriiovych - Candidate of Philological Sciences (Ph.D.), Docent, Vice-Rector for Academic and Scientific Work, H. S. Skovoroda Kharkiv National Pedagogical University; 29 Alchevskykh Str., Kharkiv, 61002, Ukraine.

Надійшла до редакції 7 березня 2021 року

\section{CITATION}

ДСТУ 8302:2015: Борисов В. А. Метафора в освітньому дискурсі. Лінгвістичні дослідження: зб. наук. пр. Харк. нац. пед. ун-ту імені Г. С. Сковороди. Харків, 2021. Вип. 54. Ч. II. С. 13-22. DOI: https://doi.org/10.34142/23127546.2021.54.2.02

AРА: Борисов, В. А. (2021). Метафора в освітньому дискурсі. Лінгвістичні дослідження, 54 (II), 13-22. DOI: https://doi.org/10.34142/23127546.2021.54.2.02 